\title{
PROFIL ANALOGICAL REASONING SISWA SMA
}

\author{
Riyadhotus Sholihah ${ }^{1}$, Joko Siswanto ${ }^{2}$, Fenny Roshayanti ${ }^{3}$ dan Ary Susatyo Nugroho ${ }^{4}$ \\ 1,2,3,4 Pendidikan IPA Program Pascasarjan, Universitas PGRI Semarang, Semarang, 50.232, Indonesia
}

Email: ${ }^{1}$ riasolihah3@gmail.com; ${ }^{2}$ jokosiswanto@ upgris.ac.id; ${ }^{3}$ fennyroshayanti@upgris.ac.id; ${ }^{4}$ arysusatyo@ upgris.ac.id

Diajukan: 19 January 2021; Diterima: 20 February 2021; Diterbitkan: 30 April 2021

\begin{abstract}
Abstrak: Analogical reasoning merupakan kemampuan memecahkan masalah dengan mencari persamaan diantara dua objek yaitu objek sumber dan target. Tujuan penelitian ini untuk mengetahui profil analogical reasoning siswa SMA N 16 Semarang. Penelitian ini termasuk kedalam penelitian kualitataif dengan Teknik pengumpulan data yang digunakan survey dengan mengerjakan soal analogical reasoning. Subyek penelitian 100 siswa kelas X. Hasil yang ditemukan dalam penelitian ini adalah kategori kemampuan analogical reasoning siswa SMA N 16 Semarang rendah dengan frekuensi 74 dan presentase 73,6\%. Rendahnya kemampuan analogical reasoning siswa dipengaruhi kurangnya metode pembelajaran yang mendorong siswa dalam pemecahan masalah menggunakan analogi, selain itu analogi memiliki dua sisi jika dipahami akan mempermudah pemahaman siswa terhadap konsep, namun jika tidak bisa diapahami akan terjadi miskonsepsi sehingga guru jarang menggunakan penalaran analogi dalam menjelaskan materi abstrak. Oleh karena itu perlu adanya pemahaman dan pengalaman terhdap guru untuk membangun kemampuan ini dengan menggunakan metode pembelajaran yang mendukung kemampuan analogical reasoning.
\end{abstract}

Kata Kunci: profil, analogical reasoning, metode pembelajaran

\begin{abstract}
Analogical reasoning is the ability to solve problems by finding similarities between two objects, namely source and target objects. The purpose of this study was to determine the analogical reasoning profile of students at SMA N 16 Semarang. This study is included in a qualitative study with data collection techniques used in surveys by working on analogical reasoning problems. The research subjects were 100 students of class $X$. The results found in this study were the category of analogical reasoning ability of students of SMA N 16 Semarang low with a frequency of 74 and a percentage of $73.6 \%$. The low ability of analogical reasoning students is influenced by the lack of learning methods that encourage students in problem-solving using analogies, besides analogies have two sides if understood will facilitate students' understanding of concepts, but if it cannot be understood misconceptions occur so teachers rarely use analogous reasoning in explaining material abstract. Therefore it is necessary to have an understanding and experience of the teacher to build this ability by using learning methods that support analogical reasoning abilities.
\end{abstract}

Keywords: profiles, analogical reasoning, learning methods

\section{Pendahuluan}

Abad 21 lebih dikenal dengan abad pengetahuan dengan terjadinya perubahan pola pikir masyarakat (Soh, Arsad \& Osman, 2010). Generasi masa depan yang diharapkan untuk mengimbangi perubahan yang terjadi pada abad 21 dengan mewujudkan generasi yang memiliki kemampuan berpikir kreatif dan menyelesaikan masalah, kreativitas dan inovasi, kolaborasi, serta komunikasi (National Education Association, 2012). Kemampuan tersebut termasuk kedalam kecakapan berpikir , untuk mewujudkan kemampuan tersebut diperlukan adanya Pendidikan. Pendidikan memiliki peran penting dalam menciptakan generasi masa depan dengan kemampuan tersebut.

Kecakapan berpikir merupakan kemampuan yang harus dimiliki setiap orang.
Oleh karena itu kecakapan berpikir sangat penting dipelajari di sekolah. Salah metode yang dapat menumbuhkan kemampuan tersebut adalah menggunakan analogi (Kusumaningrum, 2013). Analogi merupakan perwujudan suatu hal yang berbeda dan dibandingkan dengan tujuan mencari persamaan tanpa melihat perbedaan, Oleh karena itu, dalam proses mencari persamaan diantara dua objek, seseorang perlu berpikir (Gentner, 1989)

Penalaran analogi dapat diterapkan dalam materi biologi, karena karakteristik ilmu biologi mengkaji materi abstrak seperti prosesproses metabolisme kimiawi, sistem sirkulasi, hormonal koordinasi dan lain-lain, dimana materi tersebut tidak dapat dilihat prosesnya secara langsung (Sudarsiman, 2015). Oleh karena itu pembelajaran biologi di sekolah 
perlu ditekankan pada pembelajaran berbasis kontekstual tidak hanya tekstual, karena belajar biologi lebih menekankan pada mengkaitkan materi pembelajaran dengan dunia nyata yang dihadapi siswa sehari-hari baik dalam lingkungan keluarga, masyarakat, alam sekitar dan dunia kerja, sehingga siswa mampu membuat hubungan antara pengetahuan yang dimilikinya dengan penerapannya dalam kehidupan sehari-hari (Machin, 2014). Interaksi tersebut melatih siswa mengerti bagaimana belajar, mengembangkan potensi rasional pikir, keterampilan, dan kepribadian serta mengenal permasalahan biologi dan mengkajinya (Suratsih, 2010).

Kemampuan berpikir analogi dapat membentuk perseptif dan menyelesaikan masalah. Pola berpikir analogi adalah membandingkan dua permasalahan dengan menggunakan masalah sumber dan masalah target, dimana masalah sumber adalah masalah yang sudah dipelajari sedangkan masalah target adalah masalah yang akan dipecahkan dengan mencari kesamaan dari masalah sumber.

Berpikir dan kemampuan argumentasi sangat penting di era digitalisasi, dengan adanya kemampuan analogi dapat menunjang kemampuan berpikir tingkat tinggi dan kemampuan penyelesaian masalah, maka perlu adanya perhatian dalam proses pembelajaran biologi di sekolah menengah. Hal ini juga didukung hasil penelitian Yuningsih (2018) menyatakan bahwa pembelajaran dengan pendekatan analogi dapat menciptakan pembelajaran yang bermakna bagi siswa dalam memahami materi biologi.

Berdasarkan pemaparan diatas menunjukkan proses berpikir analogi siswa perlu diperhatikan. Oleh karena itu perlu adanya penelitian tentang profil analogical reasoning siswa SMA dengan tujuan untuk mengetahui kemampuan berpikir analogi siswa SMA kelas X SMA 16 Semarang.

\section{Metode Penelitian}

Jenis penelitian ini adalah penelitian deskriptif kualitatif. Penelitian ini dilaksanakan pada bulan Januari 2020. Sumber data dalam penelitian ini adalah siswa kelas $\mathrm{X}$ SMA N 16 Semarang dengan teknik sampling menggunakan Propotionate Stratified Random
Sampling dengan jumlah populasi 100 siswa. Teknik pengumpulan data dalam penelitian ini adalah survei dengan mengerjakan soal analogical reasoning dan wawancara. Metode analisis data menggunakan triangulasi data kemudian dikategorikan menurut Ratumanan dan Laurent (2011).

\section{Hasil Penelitian dan Pembahasan}

Dari data tentang profil daripada analogical reasoning siswa kelas X SMA N 16 Semarang dapat ditunjukkan pada Tabel 1. Profil analogical reasoning. Sehingga terlihat sangat jelas tentang keberadaan dari seluruh tabel yang ada tersebut.

Tabel 1 Presentase Analogical reasoning siswa SMA N 16 Semarang

\begin{tabular}{rcccc}
\hline No. & Kriteria & Rentang & Frekuensi & $\begin{array}{c}\text { Persentase } \\
(\%)\end{array}$ \\
\hline 1 & Tinggi & $\begin{array}{c}85 \leq \mathrm{N} \leq \\
100\end{array}$ & 4 & 3,8 \\
2 & Sedang & $\begin{array}{c}75 \leq \mathrm{N}<85 \\
3\end{array}$ & 24 & 22,6 \\
& Rendah & $\mathrm{N}<75$ & 74 & 73,6 \\
\hline
\end{tabular}

Ratumanan dan Laurent, 2011)

Berdasarkan hasil penelitian yang dilakukan di SMA N 16 Semarang ditemukan kemampuan Analogical reasoning siswa kelas $\mathrm{X}$ dengan frekuensi 74 dan presentase $73,6 \%$ dengan kategori rendah.

Rendahnya kemampuan Analogical reasoning menunjukkan bahwa penalaran siswa dalam pemecahan masalah dengan pola pikir analog pada bidang sains terutama biologi tergolong rendah, jika kemampuan berpikir analog rendah maka berpengaruh terhadap kemampuan berpikir kritis dan kreatif siswa, karena kemampuan berpikir analog juga memacu berpikir kritis dan kreatif (Kristayulita, As'ari, \& Sa;dijah , 2017).

Rendahnya kemampuan analogical reasoning yang ditemukan dalam penelitian ini dipengaruhi oleh berbagai hal diantaranya pengetahuan setiap siswa terhadap pengalaman yang dimiliki berbeda, metode belajar yang digunakan oleh guru tidak mengunakan metode yang mengajak siswa untuk berpikir analogi dalam pemecahan masalah. Hal ini sesuai dengan hasil wawancara dengan guru yang menyatakan ragu menganalogikan suatu konsep. Pendapat tersebut diperkuat Harrison (2013) guru jarang menggunakan metode analogi dalam proses 
belajarnya dikarenakan pembelajaran yang menerapkan metode analogi memiliki dua mata pisau, jika menganalogikan suatu konsep tidak dipahami siswa akan menyebabkan miskonsepsi, namun jika penggunaan analogi dapat dipahami oleh siswa maka akan mempercepat pemahaman konsep yang bersifat abstrak.

Hal ini dapat dilihat dari kata Analogical reasoning berasal dari analog, analog merupakan bentuk dari kesamaan sifat dengan cara membandingkan antara dua unsur yang tidak serupa atau berbeda untuk mempermudah transfer informasi dengan sumber analogi yang fameliar untuk target yang asing (Orgill \& Bodner, 2006). Sedangkan Analogical reasoning atau penalaran analogi merupakan penalaran yang digunakan untuk materi-materi tertentu dengan tujuan untuk menyimpulkan informasi yang didapatkan (Gentner, 1983). Selain itu Mofidi (2012) berpendapat bahwa penalaran analogi merupakan proses berpikir dengan tujuan mendapatkan kesimpulan atau pengetahuan baru dengan cara membandingkan antar objek analogi atau dengan pengetahuan-pengetahuan sebelumnya sesuai dengan pengalaman yang dimiliki.

Analogi dimanfaatkan untuk mempermudah penyampaian materi yang bersifat abstrak, terutama pada materi biologi, materi biologi mempelajari tentang makhluk hidup dan lingkungan sekitar serta mempelajari komponen dan proses-proses yang abstrak yang terjadi dalam tubuh makhluk hidup (Sholihah, 2019), dengan adanya analogi mempermudah pemahaman siswa. Pembelajaran dengan penggunaan analogical reasoning dapat memotivasi siswa dalam belajar dan membangun suasana pembelajaran yang menyenangkan sehingga dapat meningkatkan pemahaman siswa terhadap konsep ilmiah (Harrison, 2013). Selain itu analogical reasoning dapat digunakan untuk memecahkan masalah.

Kemampuan pemecahan masalah dengan menggunakan Analogical reasoning memiliki alur sebagai berikut, penyajian topik permasalahan dalam bentuk ilustrasi masalah target dengan masalah sumber, kemudian mencari persamaan dengan cara pemetaan kesamaan, kemudian peserta didik melakukan evaluasi, setelah itu peserta didik menarik kesimpulan. Kunci dalam penggunaan penalaran ini adalah pengetahuan berdasarkan pengalaman yang dimiliki oleh masing-masing peserta didik. (Yuningsih, 2018)

Analogical reasoning merupakan salah satu pendekatan konstruktivisme (Harrison, 2013). Pendekatan konstruktivisme merupakan pendekatan yang menekankan pada aktivitas siswa dalam membangun pengetahuannya sendiri (Trianto, 2009). Keterampilan yang mendukung dalam pendekatan ini adalah siswa diberikan kebebasan dalam mengemukakan pendapat dengan tujuan untuk memecahkam masalah yang dihadapi, kreatif dan dapat mempertanggungjawabkan argumentasi secara rasional (Subekti, 2010). Sehingga pembelajaran dengan menekankan analogical reasoning dalam pembelajaran biologi disarankan untuk dilaksanakan di kegiatan belajar mengajar.

Solusi yang ditawarkan guna meningkatkan kemampuan analogical reasoning dalam materi biologi adalah guru memberikan stimulus yang mendukung siswa dalam berpikir analogi, penggunan metode pembelajaran dengan penerapan pendekatan analogi terhadap materi yang memiliki cakupan materi kompleks dan abstrak seperti pada materi ekosistem, sel, system peredaran darah, sistem imun dan lain-lain. Metode pembelajaran yang digunakan berupa metode FAR (The Focus, Action, Reflection), metode TWA (Teaching With Analogy), metode GMAT (The General Model of Analogy Teaching) (Yuningsih \& Susilo, 2018), dan penggunaan media yang sesuai dengan materi.

\section{Kesimpulan dan Rekomendasi}

Profil analogical reasoning siswa kelas X SMA N 16 Semarang memiliki kategori rendah. Kategori rendah menunjukkan kemampuan berpikir tingkat tinggi siswa dalam hal ini penalaran analogi yang dimiliki rendah. Hal ini disebabkan karena metode pembelajaran yang digunakan guru tidak mendorong siswa menyelesaikan masalah dengan analog. Selain itu juga terdapat kekwatiran dalam penerapan analog dalam kegiatan belajar mengajar.

Rekomendasi yang disarankan peneliti adalah perlu dilakukan pemahaman terhadap tenaga guru terhadap penggunaan pengajaran 
dengan mendorong penalaran analog dengan benar, selain pemahaman juga perlu dilakukan pelatihan penggunaan metode pembelajaran yang mendukung penalaran analogi seperti dalam pengajaran menggunakan metode FAR, TWA, dan lain-lain.

\section{Daftar Pustaka}

Gentner, D. (1983). Structure-Mapping: A Theoretical Framework for Analogy. Cognitive science, 155-170.

Gentner, D. (1989). The mechanisms of analogical learning: In S. Vosniadou, and A. Ortony (Eds.), Similarity and analogical reasoning.

Harrison, Allan G. \& Coll, Richard K. 2013. Analogi dalam Kelas Sains. Jakarta: Indeks

Kristayulita, As'ari, A. R., \& Sa;dijah , C. (2017). Masalah Analogi: Kajian Teoritik Skema Penalaran Analogi. SI MaNIs (Seminar Nasional Interasi Matematika dan Nilai Islami) (pp. 435-441). Mataram : Prosiding
SI MaNIs (Seminar Nasional Interasi Matematika dan NIlai Islami) Vo. 1. No.1.

KUSUMA NINGRUM, R. E. T. N. O. (2013). Profil Penalaran Permasalahan Analogi Siswa Sekolah Menengah Pertama Ditinjuau Dari Perbedaan Gender. MATHEdunesa, 2(3).

Machin, A. (2014). Implementasi pendekatan saintifik, penanaman karakter dan konservasi pada pembelajaran materi pertumbuhan. Jurnal Pendidikan IPA Indonesia, 3(1).

Mofidi, S., Amiripour, P., \& Bijan - Zadeh, M.H. 2012. Instruction of Mathematical Concepts Through Analogical Reasoning Skill. Indian Journal of Science and Technology, 5: 2916-2923

National Education Association. (2012). Preparing 21st century students for a global society: An educator's guide to the "Four Cs". Alexandria, VA: National Education Association. 